\title{
IMPLEMENTASI ETNOMATIKA BERBASIS PERMAINAN TRADISIONAL TERHADAP BERPIKIR KRITIS DENGAN KOVARIABEL KEMAMPUAN VERBAL SISWA KELAS II SD
}

\author{
I.M. Alit Darmawan ${ }^{1}$, Sariyasa ${ }^{2}$, I.M. Gunamantha ${ }^{3}$ \\ ${ }^{123}$ Program Studi Pendidikan Dasar \\ Universitas Pendidikan Ganesha \\ Singaraja, Indonesia \\ e-mail: darmawan@undiksha.ac.id ${ }^{1}$, sariyasa@undiksha.ac.id ${ }^{2}$, \\ made.gunamantha@undiksha.ac.id ${ }^{3}$
}

\begin{abstract}
Abstrak
Saat ini pembelajaran berbasis budaya tidak selalu diterapkan dalam kurikulum sekolah, termasuk pada kegiatan belajar mengajar di sekolah. Salah satu bentuk pembelajaran berbasis budaya adalah etnomatematika. Budaya permainan tradisional curik-curik tanpa disadari dapat diterapkan pada konsep matematika, khususnya materi waktu. Tujuan penelitian adalah untuk mengetahui pengaruh implementasi pendekatan pembelajaran Etnomatematika berbasis permainan tradisional curik-curik terhadap kemampuan berpikir kritis siswa ditinjau dari kemampuan verbal siswa kelas II SD di Gugus Pattimura Kecamatan Denpasar Selatan. Data dianalisis menggunakan ANAKOVA dengan bantuan SPSS 21.0 for windows. Sebanyak 63 siswa kelas II dipilih sebagai sampel dengan teknik random sampling. Data yang dikumpulkan adalah data kemampuan berpikir kritis dengan tes essai dan kemampuan verbal siswa dengan tes pilihan ganda. Hasil penelitian menunjukan bahwa: pertama, terdapat perbedaan yang signifikan terhadap kemampuan berpikir kritis siswa antara siswa yang menerapkan pendekatan etnomatematika dan siswa yang mengikuti model pembelajaran konvensional ( $F_{\text {hitung }}=7,071>F_{\text {tabel }}=3,998$ ). Kedua, setelah dikendalikan oleh kovariabel kemampuan verbal, terdapat perbedaan yang signifikan antara kemampuan berpikir kritis siswa yang mengikuti pendekatan pembelajaran etnomatematika dan siswa yang mengikuti model pembelajaran konvensional $\left(F_{\text {hitung }}=4,295>F_{\text {tabel }}=4,00\right)$. Ketiga, terdapat kontribusi kovariabel kemampuan verbal yang signifikan terhadap kemampuan berpikir kritis siswa $\left(r_{\text {hitung }}=0,570>r_{\text {tabe }} l\right.$ $=0,215)$.
\end{abstract}

Kata Kunci : Berpikir Kritis; Etnomatematika; Kemampuan Verbal

\begin{abstract}
Nowadays culture-based learning is not always applied in school curriculum, including in teaching and learning activities in schools. One form of culture-based learning is ethnomatematics. Traditional game culture name's curik-curik applicable to the concepts of mathematics,especially learning about time.The purpose of this study is to investigate the effect of implementation ethnomatematics learning approaches based on traditional game name's curik-curik on the ability of students' critical thinking in terms of verbal abilities of second grade students in cluster Pattimura subdistrict Denpasar Selatan. Data were analyzed using ANAKOVA with the help of SPSS 21.0 for windows. About 63 of second grade students were selected as sample by using random sampling technique. Data collected were data of critical thinking abilities and students's verbal learning using multiple choice test. The result shows that first, there's a significant difference in critical thinking result between students who followed ethnomatematics learning approaches and students who followed conventional learning model ( $F_{\text {hitung }}=7,071>F_{\text {table }}=3,998$ ). Second, after controlled by verbal ability covariable, there's a significant difference between critical thinking abilities in students who followed ethnomatematics learning approaches and students who followed conventional learning model $\left(F_{\text {hitung }}\right.$ $\left.=4,295>F_{\text {tabel }}=4,00\right)$. Third, there's a significant contribution of verbal ability covariable to student's critical thinking abilities $\left(r_{\text {hitung }}=0,570>r_{\text {tabe }} l=0,215\right)$.
\end{abstract}


Keywords : Critical Thinking; Etnomatematics, Verbal Ability

\section{PENDAHULUAN}

Pada era globalisasi dan revolusi industri 4.0 teknologi berkembang dengan pesat di segala sektor kehidupan. Hal tersebut tidak bisa dipungkiri, karena teknologi memudahkan pekerjaan manusia. Di dunia pendidikan teknologi sangat berperan penting dalam memberikan media-media pembelajaran yang menarik dengan jangkauan lebih luas dan nyata. Disisi lain perkembangan teknologi tersebut juga berdampak pada hilangnya nilai-nilai budaya lokal yang masih bersifat tradisional. Hal ini dikarenakan semakin pesatnya perkembangan teknologi, menyebabkan pengurangan penerapan budaya lokal dalam bentuk permainan tradisional dalam pembelajaran di sekolah-sekolah. Padahal pemahaman terhadap nilai-nilai budaya lokal sangat penting agar para siswa dapat menjadi generasi yang berkarakter dan mampu menjaga serta melestarikan budaya sebagai landasan karakter bangsa. Nilai budaya penting untuk ditanamkan pada setiap individu sejak dini, agar setiap individu mampu lebih memahami, memaknai, dan menghargai serta menyadari pentinganya nilai budaya dalam menjalankan setiap aktivitas kehidupan. Praktik budaya juga memungkinkan tertanamnya konsepkonsep matematika dan mengakui bahwa semua orang mengembangkan cara khusus dalam melakukan aktivitas matematika yang disebut etnomatematika. Etnomatematika mencakup ide-ide matematika, pemikiran dan praktik yang dikembangkan oleh semua budaya.

Pentingnya konteks kehidupan yang nyata dalam pembelajaran matematika dikemukan juga oleh Jenning \& Dunne (1999) bahwa sebagian besar siswa mengalami kesulitan dalam mengaplikasikan matematika dalam kehidupan sehari-harinya karena dalam pembelajaran matematika dunia nyata hanya dijadikan tempat mengaplikasikan konsep bukan sebagai alat dan sumber dalam mempelajari pengetahuan matematika. Untuk itulah Zeichner (Rosa \& Orey, 2011) menyarankan perlunya guru perlu mengimplementasikan prinsipprinsip kebudayaan dalam kegiatan pembelajaran, baik sebagai bahasa pengantar ataupun aktivitas sosial masyarakat yang dijadikan sumber pembelajaran. Hal ini diperkuat juga oleh Bishop (1994) bahwa integrasi nilai-nilai budaya yang ada di masyarakat sekitar dalam pembelajaran memberikan pengaruhi pada perilaku individu, serta berperan yang besar pada perkembangan pemahaman individual, termasuk pembelajaran matematika. Dengan demikian, diperlukan proses internalisasi ethnomathematics kedalam kegiatan pembelajaran matematika (Zhang \& Zhang, 2010). Supriadi (2010: 115) menyebutkan ada empat hal yang harus diperhatikan dalam pembelajaran berbasis budaya, yaitu substansi dan kompetensi bidang ilmu/ bidang studi, kebermaknaan dan proses pembelajaran, penilaian hasil belajar, serta peran budaya. Pembelajaran berbasis budaya lebih menekankan tercapainya pemahaman yang terpadu (integrated understanding) dari pada sekedar pemahaman mendalam (inert understanding).

Kemampuan verbal adalah kemampuan menjelaskan pemikiran atau kemampuan mengaitkan berbagai informasi yang diperoleh dan membuat hipotesis (Levy dan Ransdell, 1996 dalam Kumara, 2001). Kemampuan verbal yang baik diduga memiliki kecakapan yang mensyaratkan keakraban dengan bahasa tertulis maupun lisan untuk menyimak, menelaah isi dari suatu pernyataan, berani mengungkapkan ide, gagasan, pendapat, dan pikirannya,sehingga siswa tersebut dapat mengambil suatu kesimpulan yang tepat (Saregar dkk, 2013). Kemampuan verbal adalah kemampuan penalaran tentang analogi verbal yang penekanannya tertuju pada komponen penalaran bukan pada kesulitan kata-kata (Simbolon, 2014).

Beberapa penelitian yang berkaitan dengan penerapan etnomatematika ke pembelajaran memiliki peran yang positif. Penelitian oleh Suryawan and Sariyasa (2018) menemukan melalui tahap-tahap 
dalam model pengembangan produk Plomp model open-ended problem dengan konten etnomatematika yang valid, praktis, dan efektif untuk meningkatkan aktivitas dan prestasi belajar matematika siswa SMP di bidang geometri. Integrasi konten etnomathematika ke dalam open-ended problem, tersirat pada konsep dan pengetahuan yang dibangun oleh siswa menjadi nyata berdasarkan pada lingkungan mereka sehingga pengajaran menjadi lebih bermakna. Perbedaan budaya siswa mempengaruhi sudut pandang berbeda yang menciptakan pemahaman berbeda. Karenanya, penting bagi guru untuk melayani masalah matematika terbuka dengan konteks etnomatematika di awal pelajaran yang dapat digunakan sebagai jembatan untuk matematika praktis di luar kelas dan apa yang mereka pelajari dalam pelajaran formal.

Pembelajaran matematika berbasis etnomatematika diharapkan dapat meningkatkan kemampuan berpikir kritis siswa dalam meyelesaikan permasalahan geometri, dimana kemampuan berpikir kritis merupakan kemampuan berpikir tingkat tinggi yang terdiri dari elemen penting diantaranya menginterpretasi, menganalisis, mengevaluasi, serta membuat suatu keputusan untuk memecahkan suatu masalah. Khususnya bagi para siswa, etnomatematika akan membantu mereka dalam mempelajari, menganalisis dan memprektekkan kegiatan pembelajaran khususnya pada materi geometri dengan penggunaan pengejaran pemecahan masalah yang relevan dengan budaya sebagai bahan ajar dan alternatif dalam pembelajaran( Suhartini dan Adhetia, 2017)

$$
\text { Kemampuan verbal adalah }
$$

kemampuan yang menyangkut pengertian terhadap ide-ide yang diekspresikan dalam bentuk kata-kata. Aspek-aspek kemampuan verbal meliputi analogi katakata, perbendaharaan kata, dan hubungan kata-kata (Koyan, 2003, p.7). Kemampuan verbal diperlukan dalam setiap mata pelajaran, salah satunya matematika. Dalam pembelajaran matematika, kemampuan yang perlu dikuasai siswa tidak terbatas pada kemampuan berhitung saja, tetapi juga kemampuan verbal. Hal itu dikarenakan di dalam matematika banyak sekali simbol yang digunakan, baik berupa huruf maupun nonhuruf. Kemampuan verbal akan membantu siswa dalam memahami makna dan membuat model matematika untuk menyelesaikan permasalahan matematika tersebut.

Berdasarkan uraian di atas, merupakan hal yang penting untuk meneliti penerapan pendekatan pembelajaran etnomatematika terhadap kemampuan berpikir kritis siswa. Demikian pula dengan memperhatikan kemampuan verbal yang dimiliki siswa kelas II SD Gugus Pattimura Kecamatan Denpasar Selatan. Dalam konteks ini tujuan dari penelitian ini adalah 1) mengetahui perbedaan kemampuan berpikir kritis siswa antara siswa yang mengikuti pendekatan pembelajaran etnomatematika dengan model pembelajaran konvensional. 2) mengetahui perbedaan kemampuan berpikir kritis antara siswa yang mengikuti pendekatan pembelajaran etnomatematika dengan siswa yang mengikuti model pembelajaran konvensional setelah kovariabel kemampuan verbal dikendalikan.(3) mengetahui kontribusi kemampuan verbal terhadap kemampuan berpikir kritis siswa.

\section{METODE}

Jenis penelitian ini adalah penelitian eksperimen semu dengan rancangan posttest-only control-group desain. Dalam penelitian ini terdapat 2 variabel dan 1 kovariabel. 1) Variabel bebasnya adalah pembelajaran etnomatematika berbasis permainan tradisional curik-curik dan pembelajaran konvensional, 2) variabel terikat dalam penelitian ini adalah kemampuan berpikir kritis siswa, dan (3) yang menjadi kovaribel dalam penelitian ini adalah kemampuan verbal.

Seluruh siswa kelas 2 pada gugus Pattimura Kecamatan Denpasar Selatan merupakan populasi dalam penelitian ini. Berdasarkan uji kesetaraan hasil ulangan akhir semester I, ditetapkan 2 sekolah yang menjadi sampel yaitu SDN 1 Sesetan kelas IIB berjumlah 31 orang, dan SDN 7 Sesetan kelas IIA berjumlah 32 
orang dengan total sampel berjumlah 63 orang.

Dalam pelaksanaan penelitian ini, digunakan pendekatan pembelajaran etnomatematika berbasis permainan tradisional curik-curik. Kegiatan dilakukan di halaman sekolah SDN 7 Sesetan yang merupakan kelas eksperimen dalam penelitian ini. Penerapan etnomatematik melalui permainan curik-curik ini digunakan pada kurikulum 2013 yang berupa pembelajaran tematik. Matematika masih menjadi pelajaran yang dianggap sulit dan hampir hilangnya budaya lokal menjadikan etnomatematika menjadi salah satu solusi, karena menurut Kurumeh (2004) etnomatematika dapat menjelaskan realitas hubungan antara budaya lingkungan dan matematika saat mengajar. Meskipun, bukan menjadi hal baru dalam kurikulum modifikasi dengan permainan curik-curik menjadi wawasan tersendiri bagi peneliti di sekolah gugus Pattimura kecamatan Denpasar Selatan pada saat memberikan materi matematika yang tidak hanya dilakukan di dalam kelas tapi dapat juga dilakukan di luar kelas. Pertimbangan lain dari gagasan ini didasarkan dari pendapat Bishop (1994) bahwa matematika yang diperoleh di sekolah tidak cocok dengan cara hidup masyarakat setempat, sehingga sulit dipahami. Aturan permainan curik-curik yang sudah dimodifikasi dengan etnomatematika, sebagai berikut :

a. Siswa berkumpul di lapangan dan diberi aturan permainan

b. Sebelum permainan siswa membentuk lingkaran sambil bernyanyi, setelah itu siswa melakukan suit untuk menentukan tim A dan Tim B

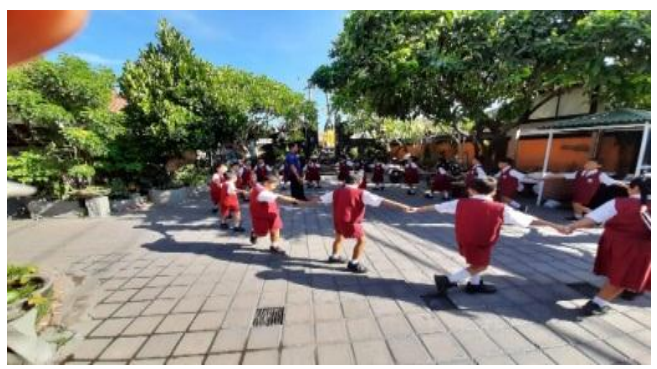

c. Aturan permainannya adalah setiap siswa yang berada dalam tangkapan setelah nyanyian selesai harus menjawab pertanyaan yang diajukan. Bagi yang menjawab dengan benar masuk ke tim $A$, bagi yang salah menjawab masuk ke tim B. Setiap sesi menjawab diberikan kepada 2 siswa, lalu dilanjutkan bernyani lagi sampai semua siswa mendapat tim.
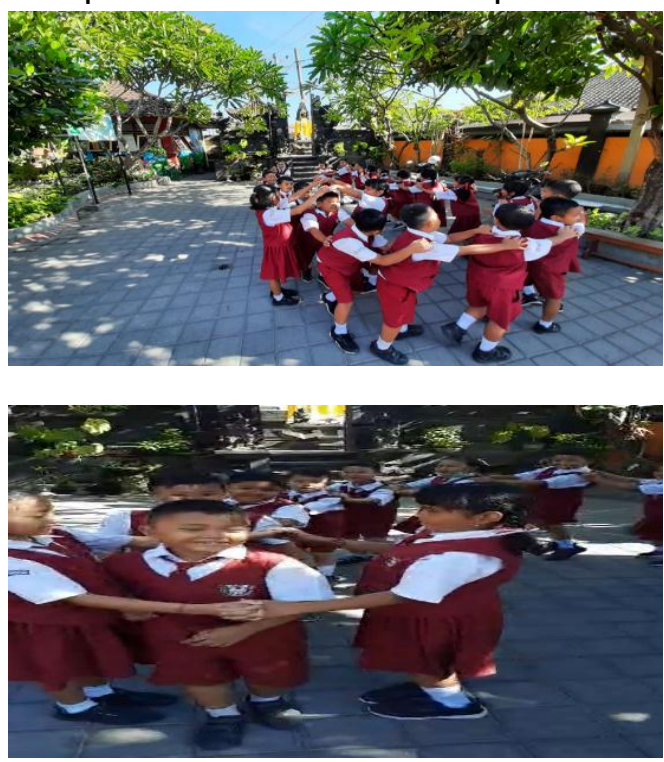

d. Permainan berakhir ketika kedua kelompok mempunyai jumlah anggota yang selisihnya sama atau selisih satu, jika salah satu kelompok mempunyai jumlah selisih lebih dari satu, maka kelompok yang kekurangan anggota harus berlari dan berusaha menarik pengikut lawan keluar barisan. Setelah terbentuk dua kelompok dengan anggota yang sama, guru memberikan lima pertanyaan berbeda pada masingmasing kelompok, kelompok yang menjawab dengan cepat dan banyak benar dinyatakan sebagai pemenang

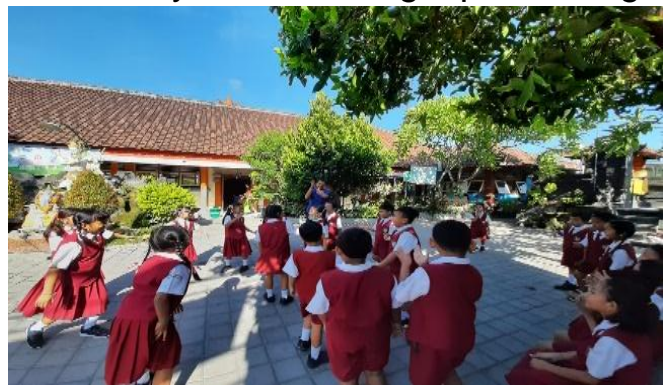

e. Pertanyaan yang diberikan adalah pertanyaan berupa kuis matematika materi tentang waktu. Pertanyaan juga berkaitan dengan kebudayaan lokal. Contoh pertanyaan :

1. Candi itu berusia 1 abad. 1 abad berapa tahun? 
2. Ayah membuat adonan lawar selama 2 hari. 2 hari berapa jam?

3. Paman membuat bale daje selama 3 bulan. 3 bulan sama dengan berapa hari?

Pertanyaan yang diberikan berkaitan dengan budaya lokal setempat.

Untuk menentukan validitas isi tes essai dan tes pilihan ganda dilakukan penilaian oleh para pakar. Setelah dianalisis, didapatkan koefisien validitas isi tes kemampuan berpikir kritis adalah 0.7, dan koefisien validitas isi tes kemampuan verbal adalah 1 . Untuk mengetahui validitas dan reliabilitas instrumen yang akan digunakan dalam penelitian dilakukan uji coba instrument. Hasil analisis instrument kemampuan berpikir kritis diperoleh validitas sebesar $r_{p b i}=0,56$ $>r_{\text {tabel }}=0,26$, dan reliabilitas sebesar $r_{1.1}=$ $0,85>r_{\text {tabel }}=0,26$. Sedangkan hasil analisis instrument kemampuan verbal diperoleh validitas sebesar $r_{p b i}=0,56>$ $r_{\text {tabel }}=0,024$, dan reliabilitas sebesar $r_{1.1}=$ $0,89>r_{\text {tabel }}=0,24$. Dengan demikian dapat disimpulkan instrumen yang digunakan dalam penelitian ini telah valid dan reliabel.

Data dalam penelitian dianalisis secara bertahap, yaitu: deskripsi data, uji prasyarat, dan uji hipotesis. Pendeskripsian data kemampuan berpikir kritis dan kemampuan verbal siswa berdasarkan tendensi data, meliputi mean, median, modus, standar deviasi, varians, rentangan, skor maksimum, dan skor minimum. Selanjutnya dilakukan perhitungan sentral dari masing-masing data untuk mencari mean, median, modus, serta standar deviasi dari tiap-tiap kelompok data tersebut. Uji prasyarat yang dilakukan adalah uji normalitas sebaran data, uji homogenitas varians, serta uji linieritas dan keberartian arah regresi. Pengujian normalitas dilakukan untuk meyakinkan bahwa sampel berasal dari populasi yang berdistribusi normal, sehingga uji hipotesis dapat dilakukan. Uji normalitas data dilakukan pada empat kelompok data.

Kelompok pertama adalah data kemampuan berpikir kritis siswa yang mengikuti pembelajaran dengan pendekatan etnomatematika, kelompok kedua adalah kemampuan verbal siswa yang mengikuti pembelajaran dengan pendekatan etnomatematika, kelompok ketiga data kemampuan berpikir kritis siswa yang mengikuti pembelajaran dengan model pembelajaran konvensional, dan kelompok keempat data kemampuan verbal siswa yang mengikuti pembelajaran dengan model pembelajaran konvensional. Uji normalitas pada keempat kelompok data menggunakan SPSS-PC 21 for Windows uji statistik Kolmonogov-smirnov pada signifikansi 0,05.

Uji homogenitas varians antar kelompok dilakukan dengan memanfaatkan bantuan SPSS-PC 21 for Windows. Data memiliki varians yang sama (homogen) jika angka signifikansi yang diperoleh lebih besar dari 0,05 dan dalam hal lain varians sampel tidak sama (tidak homogen). Uji homogenitas varians antara kelompok dimaksudkan untuk memperlihatkan bahwa dua atau lebih kelompok data sampel berasal dari populasi yang memiliki varians yang sama. Uji homogenitas varians antar kelompok menggunakan Levene's test of Equality of Error Variance (Candiasa, 2010). Uji Linieritas dimaksudkan untuk mengetahui hubungan antara varibel bebas dengan variabel terikat. Selain itu, uji linieritas juga diharapkan dapat mengukur taraf signifikansi penyimpangan dari linieritas hubungan tersebut. Apabila penyimpangan yang ditemukan tidak signifikan, maka hubungan antara variabel bebas dan varibel terikat adalah linear.

Uji ini dapat dilakukan dengan memanfaatkan bantuan SPSS-PC 21 for Windows pada taraf signifikansi 5\% dengan kriteria pengujian sebagai berikut. Untuk pengujian kelinearan garis regresi nilai $F_{\text {hitung }}$ dibandingkan dengan $F_{\text {tabel. }}$. Bila $F_{\text {hitung }}<F_{\text {tabel }}$ maka garis regresi berarti (signifikan). Untuk pengujian keberartian garis regresi nilai $\mathrm{F}_{\text {hitung }}$ (regresi) dibandingkan dengan $F_{\text {tabel }}$. Bila $F_{\text {hitung }}>$

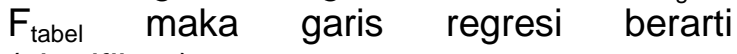
(signifikan).

Yang diuji dalam penelitian ini, meliputi: (1) Terdapat perbedaan 
kemampuan berpikir kritis siswa antara siswa yang mengikuti pendekatan Etnomatematika dengan siswa yang mengikuti Hipotesis model pembelajaran konvensional. Analisis yang digunakan adalah analisis varian satu jalur dengan kriteria pengujian: jika $F_{\text {hitung }}>F_{\text {tabel }}$ pada taraf signifikansi 5\%, maka terdapat perbedaan kemampuan berpikir kritis antara siswa yang mengkuti pendekatan pembelajaran etnomatematika dengan siswa yang mengikuti model pembelajaran konvensional. (2) Setelah kovariabel kemampuan verbal dikendalikan terdapat perbedaan kemampuan berpikir kritis siswa antara siswa yang mengikuti pendekatan Etnomatematika dengan siswa yang mengikuti model pembelajaran konvensional.

Analisis yang digunakan adalah ANAKOVA dengan kovariabel kemampuan verbal. Kriteria pengujian: jika $F_{\text {hitung }}>F_{\text {tabel }}$ pada taraf signifikansi 5\%, maka setelah kovariabel kemampuan verbal dikendalikan, terdapat perbedaan kemampuan berpikir kritis antara siswa yang mengkuti pendekatan pembelajaran etnomatematika dengan siswa yang mengikuti model pembelajaran konvensional. (3) Terdapat kontribusi signifikan kemampuan verbal terhadap kemampuan berpikir kritis siswa. Analisis yang digunakan adalah korelasi product moment dengan kriteria jika $r_{\text {hitung }}>r_{\text {tabel }}$ pada taraf signifikansi $5 \%$, maka kemampuan verbal memiliki kontribusi terhadap kemampuan berpikir kritis siswa. Sementara itu, untuk mengetahui berapa besar kontribusi kovaribel kemampuan verbal terhadap kemampuan berpikir kritis siswa, nilai koefisien korelasi product moment $\left(r_{x y}\right)$ dikuadratkan. Sehingga, nilai kontribusi kovaribel kemampuan verbal terhadap kemampuan berpikir kritis siswa adalah $r_{x y}^{2}$.

\section{HASIL DAN PEMBAHASAN}

Hasil analisis deskriptif data penelitian dapat dilihat pada tabel 1 berikut :

Tabel 1. Rekapitulasi Hasil Perhitungan Skor Kemampuan Berpikir Kritis dan Kemampuan Verbal.

\begin{tabular}{lcccc}
\hline & V1 & Y1 & X2 & Y2 \\
\hline Mean & & & & \\
Median & 63.38 & 65.00 & 55.55 & 57.98 \\
\hline Modus & 61.00 & 62.50 & 54.00 & 60.00 \\
Standar Deviasi & 50.00 & 57.50 & 52.00 & 50.00 \\
Varians & 13.37 & 13.11 & 9.63 & 18.76 \\
Rentangan & 178.69 & 171.77 & 92.72 & 351.84 \\
Skor Minimum & 50.00 & 50.00 & 38.00 & 65.00 \\
Skor Maksimum & 40.00 & 42.50 & 36.00 & 20.00 \\
\hline
\end{tabular}

Keterangan :

$\mathrm{X} 1=$ skor kemampuan berpikir kritis siswa yang mengikuti pembelajaran dengan pendekatan etnomatematika.

$\mathrm{Y} 1=$ skor kemampuan verbal siswa yang mengikuti pembelajaran dengan

pendekatan etnomatematika.

$\mathrm{X} 2$ = skor kemampuan berpikir kritis siswa yang mengikuti pembelajaran dengan model pembelajaran konvensional. 

Y2 = skor kemampuan verbal siswa yang mengikuti pembelajaran dengan model pembelajaran konvensional.

Hasil analisis deskriptif tentang kemampuan berpikir kritis siswa yang mengikuti pembelajaran dengan pendekatan pembelajaran Etnomatematika menunjukkan bahwa rata-rata skor kemampuan berpikir kritis siswa yang mengikuti pembelajaran dengan pendekatan pembelajaran Etnomatematika adalah 63,38 lebih besar dari rata-rata kemampuan berpikir kritis siswa yang mengikuti model pembelajaran konvensional yaitu sebesar 55,55. Begitupula dengan rata-rata skor kemampuan verbal siswa yang mengikuti pembelajaran dengan pendekatan pembelajaran etnomatematika yaitu sebesar 65,00 lebih besar dari rata-rata kemampuan verbal siswa yang mengikuti model pembelajaran konvensional yaitu sebesar 57,98. Oleh karena itu dapat disimpulkan bahwa kemampuan berpikir kritis siswa yang mengikuti pembelajaran dengan pendekatan pembelajaran etnomatematika lebih tinggi daripada kemampuan berpikir kritis siswa yang mengikuti model pembelajaran Konvensional.

Hasil uji normalitas sebaran data menunjukkan bahwa nilai-nilai signifikansi data pada Kolmonogov-Smirnov memiliki angka lebih besar dari 0,05 yaitu $\mathrm{X} 1=$ $0,200, Y 1=0,200, X 2=0,200, Y 2=$ 0,116 . Dengan demikian maka semua sebaran data berdistribusi normal. Hasil uji homogenitas varian antar kelompok menunjukkan angka signifikansi X1X2 dan Y1Y2 masing-masing adalah 0,073 dan 0,051 lebih besar dari 0,05. Dengan demikian, semua kelompok memiliki varians yang homogen.
Berdasarkan hasil uji linieritas regresi hasil kemampuan berpikir kritis dan kemampuan verbal siswa yang mengikuti pembelajaran dengan pendekatan etnomatematika diketahui bahwa nilai signifikansi dari Deviation from Linearity adalah 0,637 yaitu lebih besar dari pada 0,05. Dengan demikian, dapat disimpulkan bahwa bentuk regresi dari data kemampuan berpikir kritis dan kemampuan verbal siswa yang mengikuti pembelajaran dengan pendekatan pembelajaran etnomatematika memang benar linier. Sedangkan pengujian keberartian arah regresi dilakukan dengan memperhatikan Linearity.

Berdasarkan tabel di atas, nilai signifikansi Linearity sebesar 0,000 dan lebih kecil dari pada 0,05. Dengan demikian koefisien arah regresi berarti atau signifikan. Hasil uji linieritas regresi kemampuan berpikir kritis dan kemampuan verbal siswa yang mengikuti pembelajaran dengan model konvensional diketahui bahwa nilai signifikansi dari Deviation from Linearity adalah 0,522 yaitu lebih besar dari pada 0,05. Dengan demikian, dapat disimpulkan bahwa bentuk regresi dari data kemampuan berpikir kritis dan kemampuan verbal siswa yang mengikuti pembelajaran dengan model konvensional memang benar linier. Sedangkan pengujian keberartian arah regresi dilakukan dengan memperhatikan Linearity. Berdasarkan tabel yang ada, nilai signifikansi Linearity sebesar 0,048 dan lebih kecil dari pada 0,05 . Dengan demikian koefisien arah regresi berarti atau signifikan.

Berdasarkan hasil uji hipotesis 1 dengan teknik analisis varian satu jalan (ANAVA A), hasil penelitian yang diperoleh secara keseluruhan dapat dilihat pada tabel 2 .

Tabel 2. Hasil Uji Hipotesis Pertama

\begin{tabular}{|c|c|c|c|c|c|}
\hline & $\begin{array}{l}\text { Jumlah } \\
\text { Kuadrat }\end{array}$ & Df & Rata-rata Kuadrat & $\mathrm{F}$ & Sig. \\
\hline Kelompok Antar & 964.537 & 1 & 964.537 & 7.071 & .010 \\
\hline Kelompok & 8321.177 & 61 & 136.413 & & \\
\hline \multicolumn{6}{|l|}{ Dalam } \\
\hline Total & 9285.714 & 62 & & & \\
\hline
\end{tabular}


Berdasarkan hasil analisis tersebut, diperoleh $\mathrm{F}_{\text {hitung }}$ sebesar $7.071>\mathrm{F}_{\text {tabel }}=$ 3,14 dan angka signifikansi 0,010 lebih kecil dari 0,05 . Dengan demikian hipotesis nol $(\mathrm{H} 0)$ ditolak, dan hipotesis alternative (H1) yang menyatakan bahwa "terdapat perbedaan kemampuan berpikir kritis antara siswa yang mengikuti pendekatan pembelajaran Etnomatematika dengan siswa yang mengikuti model pembelajaran konvensional", diterima.

Hasil uji hipotesis pertama dalam penelitian ini telah terbukti bahwa kemampuan berpikir kritis siswa yang mengikuti pembelajaran dengan pendekatan pembelajaran Etnomatematika lebih baik daripada siswa yang mengikuti pembelajaran dengan model pembelajaran Konvensional. Hal ini disebabkan karena ada perbedaan cara atau langkah dalam penerapan pembelajarannya.

Pada model pembelajaran konvensional proses belajar mengajar lebih sering diarahkan pada "aliran informasi" atau "transfer" pengetahuan dari guru ke siswa, sehingga dalam proses pembelajaran di kelas guru yang lebih aktif, tetapi siswa cenderung pasif dan pembelajaran berpusat pada guru. Dalam model pembelajaran konvensional, pola pembelajaran atau urutan sajian materi khususnya dalam pembelajaran matematika biasanya guru mengawali dengan memberikan siswa penjelasan tentang suatu teori, defenisi, teorema yang harus dihafal, kemudian memberikan contoh soal dan diakhiri dengan latihan soal. Ketika latihan soal, siswa diberi kesempatan untuk melakukan pelatihan dan pemberian umpan balik terhadap keberhasilan siswa. Pada fase ini pula, guru jarang memberikan kesempatan kepada siswa untuk menerapkan pengetahuan dan keterampilannya yang dipelajarinya ke dalam situasi kehidupan nyata. Dalam model pembelajaran konvensional, metode ceramah merupakan pilihan utama sebagai metode pembelajaran.

Berbeda dengan pendekatan pembelajaran Etnomatematika berbasis permainan tradisional memiliki beberapa keunggulan yaitu (1) melalui pembelajaran etnomatematika materi yang disampaikan lebih mudah dipahami oleh siswa karena siswa terlibat langsung dalam pembelajaran, (2) pendekatan pembelajaran etnomatematika berbasis permainan tradisional dapat menciptakan suasana belajar yang menyenangkan dan menarik, dimana siswa dapat berinteraksi langsung, menumbuhkan rasa percaya diri, rasa ingin tahu sehingga dapat meningkatkan kemampuan berpikir kritis dalam memecahkan suatu permasalahan yang diberikan.

Berdasarkan penerapan pendekatan pembelajaran etnomatematika berbasis permainan tradisional dan data hasil analisis, secara teoritis dapat dikatakan bahwa pendekatan pembelajaran etnomatematika berbasis permainan tradisional merupakan pendekatan pembelajaran yang dapat memberikan kesempatan kepada siswa untuk membangun pengetahuannya sendiri serta memberikan kesempatan kepada siswa untuk mencari pemecahan masalah yang tepat, guru memberikan rangsangan berupa pertanyaan-pertanyaan yang nantinya siswa memberikan pendapat mereka menimbulkan rasa percaya diri siswa dalam mengemukakan pendapat serta siswa akan mencari dan mengumpulkan informasi sehingga pembelajaran yang diberikan dapat lebih bermakna. Selain itu pendekatan etnomatematika juga mengenalkan siswa agar lebih mengenal dan dapat mempertahankan kebudayaan daerah yang ada.

Temuan ini sejalan dengan penelitian yang dilakukan oleh Widiani (2020) yang berjudul Pengaruh Model Pembelajaran TGT Berbantuan Permainan Tradisional Terhadap Sikap Sosial dan Hasil Belajar PkN Siswa kelas II SD Gugus Mas. Dalam penelitiannya dinyatakan bahwa pembelajaran TGT berbantuan permainan tradisional dapat meningkatkan hasil belajar siswa kelas II SD Gugus Mas Ubud. Kajian yang dilakukan Oka relevan dengan penelitian yang dilakukan peneliti.

Uji hipotesis kedua yaitu untuk mengetahui perbedaan skor kemampuan berpikir kritis antara siswa yang mengkuti 
pendekatan

Etnomatematika dengan mengikuti pembelajaran

siswa yang pembelajaran konvensional setelah dikendalikan kovariabel kemampuan verbal disajikan pada tabel 3.

Tabel 3. Rangkuman Hasil Analisis Skor Kemampuan Berpikir Kritis dan Kemampuan Verbal Siswa

\begin{tabular}{lrrrrr}
\hline \multicolumn{1}{c}{ Sumber } & $\begin{array}{c}\text { Tipe III Jumlah } \\
\text { Kuadrat }\end{array}$ & Df & Rata-rata Kuadrat & F & Sig. \\
\hline Model & $2867.186^{\mathrm{a}}$ & 2 & 1433.593 & 13.401 & .000 \\
Perbaikan & & & & & \\
Hambatan & 5738.374 & 1 & 5738.374 & 53.642 & .000 \\
Y1Y2 & 1902.649 & 1 & 1902.649 & 17.786 & .000 \\
Kelompok & 437.471 & 1 & 437.471 & 4.089 & .048 \\
Error & 6418.528 & 60 & 106.975 & & \\
Total & 232500.000 & 63 & & & \\
Total Perbaikan & 9285.714 & 62 & & & \\
\hline
\end{tabular}

Berdasarkan hasil analisis data tersebut, diperoleh harga Fhitung sebesar 4,089 > Ftabel $=3,14$ dan angka signifikansi 0,048 lebih kecil dari 0,05. Dengan demikian hipotesis nol $(\mathrm{H} 0)$ ditolak, dan hipotesis alternative $(\mathrm{H} 1)$ yang menyatakan bahwa "terdapat perbedaan skor kemampuan berpikir kritis antara siswa yang mengikuti pendekatan pembelajaran etnomatematika dengan siswa yang mengikuti model pembelajaran konvensional", diterima.

Setelah kovariabel kemampuan verbal dikendalikan, terdapat perbedaan skor kemampuan berpikir kritis. Hal ini disebabkan karena perbedaan cara atau langkah dalam penerapan pendekatan pembelajaran etnomatematika dan model pembelajaran konvensional. Pada model pembelajaran konvensional proses belajar mengajar lebih berpusat kepada guru.

Berbeda dengan pendekatan pembelajaran etnomatematika yang melibatkan para siswa dalam proses pembelajaran. Siswa aktif dalam proses belajar yang dikemas dalam permainan.
Sehingga siswa tidak merasa bosan dalam belajar, guru maupun siswa menjadi lebih aktif.(1) Penerapan pendekatan etnomatematika berbasis permainan tradisional dapat menumbuhkan rasa percaya diri pada siswa, sehingga siswa merasa nyaman dalam menyampaikan pendapatnya karena pada pelaksanaannya siswa dekat dengan guru.(2) siswa tidak meraba / menerka hal-hal yang dipelajarinya karena pemberian materi juga langsung berkaitan dengan lingkungan sekitar siswa.(3) siswa mengenal kebudayaan daerah yang ada didaerahnya, sehingga secara tidak langsung kebudayaan daerah tetap terjaga. Disamping memperoleh pemahaman yang lebih mendalam, dan hasil belajar lebih baik, pendekatan pembelajaran etnomatematika juga mampu meningkatkan kebaikan budi, kepekaan dan toleransi.

Hipotesis ketiga yang menyatakan terdapat kontribusi kemampuan verbal siswa terhadap kemampuan berpikir kritis siswa disajikan pada tabel 4 . 


\section{Tabel 4. Rangkuman Hasil Analisis Kontribusi Kemampuan Verbal Terhadap Kemampuan Berpikir Kritis Siswa}

\begin{tabular}{llcrl} 
& \multicolumn{4}{c}{ Model Ringkasan } \\
\hline Model & $\mathrm{R}$ & $\mathrm{R}$ & $\begin{array}{c}\text { Keselarasan } \mathrm{R} \\
\text { Kuadrat }\end{array}$ & Std. tafsiran kesalahan \\
\hline 1 & $.512^{\mathrm{a}}$ & .262 & .250 & 10.60158 \\
\hline
\end{tabular}

Dari data perhitungan di atas menunjukkan kontribusi kovaribel kemampuan verbal terhadap skor kemampuan berpikiri kritis siswa, hal tersebut ditunjukan dengan melihat harga $r_{\text {hitung }}$ sebesar 0,512 yang lebih besar dari pada $r_{\text {table }}(0,246)$. Koefisien determinasi $r$ square sebesar 0,250 yang berarti $25 \%$ perubahan pada skor kemampuan berpikir kritis dapat diterangkan oleh kemampuan verbal. Dengan demikian, kemampuan verbal memang berkontribusi positif terhadap kemampuan berpikir kritis siswa.

Temuan ini juga didukung oleh penelitian Ari Irawan dan Gita Kencanawaty tahun 2016 yang berjudul Peranan Kemampuan Verbal Dan Kemampuan Numerik Terhadap Kemampuan Berpikir Kritis Matematika Siswa Kelas XI di Kota Depok. Dalam penelitiannya dinyatakan terdapat pengaruh yang signifikan antara kemampuan verbal dan kemampuan numerik secara bersama-sama terhadap kemampuan berpikir kritis matematika. Terdapat pengaruh yang signifikan antara kemampuan verbal terhadap kemampuan berpikir kritis matematika.

Penelitian lain yang mendukung temuan ini adalah penelitian oleh Ria Wijayanti dan Anita Trisiana yang berjudul Pengaruh Permainan Engklek Berbasis Etnomatematika Terhadap Kemampuan Berpikir Kritis Peserta Didik Kelas III Materi Bangun Datar SD Muhammadiyah 22 Sruni Surakarta Tahun Pelajaran 2017/2018. Hasil temuannya adalah Berdasarkan hasil analisis data statistik menggunakan rumus Paired Sample TTest tentang Pengaruh Permainan Engklek Berbasis Etnomatematika Terhadap Kemampuan Berpikir Kritis Peserta Didik Kelas III Materi Bangun Datar SD Muhammadiyah 22 Sruni Surakarta terdapat nilai korelasi sebesar
0,685 menunjukkan bahwa hubungan kedua variabel kuat. Diperoleh -thitung yaitu sebesar -16,833 selanjutnya -thitung dibandingkan dengan -ttabel dengan d.b $=(\mathrm{N}-1)$ jadi $(35-1)=34$ dalam taraf signifikansi 5\% yaitu -2,032 atau -16,833 < $-2,032$ sedangkan berdasarkan nilai sig sebesar $0,000<0,05$ maka Ho ditolak dan $\mathrm{Ha}$ diterima.

Pembelajaran dengan pendekatan pembelajaran Etnomatematika berbasis permainan tradisional dimulai dengan adanya penanaman konsep/ istilah yang terdapat pada materi pembelajaran, kemudian guru memberikan pertanyaan ke siswa dengan menggunakan istilah yang berkaitan dengan matematika dan kebudayaan. Dalam penerapannya siswa diberikan pertanyaan kuis dan dijawab secara langsung oleh siswa. Setelah permainan berakhir guru dan siswa berinteraksi dan membahas jawaban dari pertanyaan yang belum dijawab dengan benar. Dalam hal ini juga siswa menyampaikan pendapatnya sehingga menjadikan pembelajaran lebih menarik dan siswa akan lebih aktif mengikuti serta pembelajaran akan menjadi lebih bermakna. Keadaan seperti ini menunjukkan bahwa pendekatan pembelajaran etnomatematika berbantuan permainan tradisional dalam setiap pembelajaran menuntut kesiapan, baik dari pihak guru maupun dari pihak siswa. Guru berperan sebagai fasilitator, sedangkan siswa disini harus terlibat aktif dalam pembelajaran dengan mengoptimalkan kemampuan berpikir kritis dan verbal siswa.

\section{PENUTUP}

Berdasarkan hasil pengujian hipotesis dan pembahasan, maka dapat ditarik simpulan sebagai berikut.(1) terdapat perbedaan skor kemampuan 
berpikir kritis antara siswa yang mengikuti pendekatan pembelajaran etnomatematika dengan siswa yang mengikuti model pembelajaran konvensional. Skor kemampuan berpikir kritis siswa yang mengikuti pendekatan pembelajaran etnomatematika lebih tinggi dari pada siswa yang mengikuti model pembelajaran konvensional. Kualifikasi skor kemampuan berpikir kritis siswa yang mengikuti pendekatan pembelajaran etnomatematika berada pada katagori tinggi, sedangkan siswa yang mengikuti model pembelajaran konvensional berapada pada katagori sedang.(2) setelah kovariabel kemampuan verbal dikendalikan terdapat perbedaan skor kemampuan berpikir kritis antara siswa yang mengikuti pendekatan pembelajaran etnomatematika dengan siswa yang mengikuti model pembelajaran konvensional.(3) terdapat kontribusi kemampuan verbal terhadap kemampuan berpikir kritis siswa.

Berdasarkan kesimpulan di atas, beberapa saran yang diajukan adalah sebagai berikut. Bagi guru sekolah dasar diharapkan mencoba menerapkan pendekatan pembelajaran etnomatematika berbasis permainan tradisional dalam pembelajaran. Hal ini perlu dilakukan karena penerapan pendekatan pembelajaran etnomatematika selain meningkatkan hasil belajar matematika siswa juga dapat mengenalkan kebudayaan daerah yang ada. Di samping itu, bila guru ingin mengembangkan kompetensi siswa sebaiknya guru selalu mencoba model-model pembelajaran inovatif lainnya yang memungkinkan dapat mengembangkan kompetensi yang diinginkan. Dalam pembelajaran hendaknya siswa dipandang sebagai subyek yang aktif untuk mencari dan menemukan pengetahuan. Pembelajaran yang dirancang hendaknya dapat membuat siswa lebih aktif dan berusaha menemukan pengetahuan yang diinginkan. Penugasan dalam bentuk diskusi juga baik untuk menumbuhkan rasa kebersamaan. Siswa yang menemukan sendiri pengetahuan akan lebih memahami dan mengingat apa yang dipelajari. Dengan demikian, pengetahuan yang dimiliki akan melekat lebih kuat dan menjadi pengetahuan awal yang kuat untuk mempelajari pengetahuan baru. Bagi peneliti lain yang ingin mendalami penerapan pendekatan pembelajaran etnomatematika diharapkan dapat melakukan penelitian yang lebih memadai. Misalnya penelitian tentang berbagai kendala yang terjadi dalam penelitian ini yang menyebabkan hasil belajar belum optimal.

\section{DAFTAR RUJUKAN}

Bishop, J.A. (1994). Cultural Conflicts in the Mathematics Education of Indigenous People. Clyton, Viktoria: Monash University.

Candiasa, I Md. 2010. Statistik Multivariat Disertai Aplikasi dengan SPSS. Singaraja: Unit Penerbitan Universitas Pendidikan Ganesha.

Daniyati, N A. dan Sugiman. 2015. Hubungan Antara Kemampuan Verbal, Kemampuan Interpersonal, dan Minat Belajar dengan Prestasi Belajar Matematika. Pythagoras: Jurnal Pendidikan Matematika Volume 10 - Nomor 1, Juni 2015, (5060). online at: http://journal.uny.ac.id/index.php/ pythagoras

Irawan, Ari dan Gita K. 2016. Peranan Kemampuan Verbal Dan Kemampuan Numerik Terhadap Kemampuan Berpikir Kritis Matematika. e-ISSN 2442-5419 Vol. 5, No. 2 (2016) 110-119.

Jennings, S. dan Dunne. (1999). Math Stories, Real Stories, Real-life Stories.

Koyan, I. W. (2003). Pengaruh metode pembelajaran kooperatif dan kemampuan penalaran verbal terhadap hasil belajar pendidikan pancasila dan kewarganegaraan (PPKn). Jurnal Pendidikan dan Pengajaran IKIP Negeri Singaraja, No. 1 TH. XXXVI Januari 2003. ISSN 0215-8250.

Kumara, Amitya. 2001. Dampak kemampuan verbal terhadap 
ekspresi tulis. Jurnal Psikologi, Vol.1, No.1, Hal 35-40

Kurumeh. 2004. Pengaruh Pendekatan Pengajaran Ethnomatematics Pada Prestasi Sisa Dan Minat Dalam Geometri Dan Pengukuran. Tesis Ph.D yang tidak dipublikasikan. Universitas Nigeria, Nsukka.

Rosa, M. \& Orey, D. C. 2011. Ethnomathematics: the cultural aspects of mathematics. Revista Latinoamericana

Etnomatemática, 4(2). 32-54

Saregar, Antomi dkk.2011. Pembelajaran Fisika Kontekstual Melalui Metode Eksperimen dan Demonstrasi Diskusi Menggunakan Multimedia Interaktif Ditinjau dari Sikap IImiah dan Kemampuan Verbal Siswa.

Simbolon, Naeklan. 2014. Pengaruh pendekatan pembelajaran dan kemampuan verbal terhadap kemampuan berbicara bahasa inggris siswa SMA Negeri 14 dan 21 Medan. Cakrawala Pendidikan. Vol.2, No.3, Hal 225235.

Suhartini dan Adhetia, M. 2017. Meningkatkan Kemampuan Berpikir Kritis Pada Pembelajaran Geometri Berbasis Etnomatematika. Jurnal Gantang Vol. Ii, No. 2, September 2017.

Online di: http://ojs.umrah.ac.id/index.php/g antang/index

Supriadi, Pembelajaran Etnomatematika dengan Media Lidi dalam Operasi Perkalian Matematika untuk Meningkatkan Karakter Kreatif dan Cinta Budaya Lokal, Jurnal Seminar Nasional STKIP Siliwangi, Serang: Sekolah Pascasarjana UPI, 2010

Suryawan, I P.P. dan Sariyasa. 2018. J. Phys .: Conf. Ser. 1040012033
Widiani, V. A A O. 2020. Pengaruh Model Pembelajaran Tgt Berbantuan Permainan Tradisional Terhadap Sikap Sosial Dan Hasil Belajar Pkn Siswa Kelas II SD Gugus Mas Ubud. Termuat pada Pendasi, Jurnal Pendidikan Dasar Indonesia, Vol. 4 No. 1, Pebruari 2020.

Wijayanti, Ria dan Anita Trisiana. 2018. Pengaruh Permainan Engklek Berbasis Etnomatematika Terhadap Kemampuan Berpikir Kritis Peserta Didik Kelas III. Termuat pada jurnal Sinektik, Vol. 1 No. 2, Desember 2018. Surakarta : Universitas Slamet Riyadi.

Zhang, W. dan Zhang, Q, 2010. "Ethnomathematics and Its Integration within the Mathematics Curriculum". Journal of Mathematics Education, Volume 3 No. 1. Pp.151-157. 